\title{
Os gêneros Lepidopilidium, Lepidopilum, Pilotrichum e Thamniopsis (Pilotrichaceae, Bryophyta) no Estado do Rio de Janeiro, Brasil ${ }^{1}$
}

\author{
Thaís de Freitas Vaz ${ }^{2,4}$ e Denise Pinheiro da Costa ${ }^{3}$
}

Recebido em 12/01/2006. Aceito em 28/06/2006

\begin{abstract}
RESUMO - (Os gêneros Lepidopilidium, Lepidopilum, Pilotrichum e Thamniopsis (Pilotrichaceae, Bryophyta) no Estado do Rio de Janeiro, Brasil). A família Pilotrichaceae está bem representada no Estado do Rio de Janeiro, onde ocorrem 11 gêneros e 35 espécies. O trabalho trata das 17 espécies dos gêneros Lepidopilidium (Müll. Hal.), Lepidopilum (Brid.) Brid., Pilotrichum P. Beauv. e Thamniopsis (Mitt.) M. Fleisch. presentes no Estado do Rio de Janeiro. São apresentadas descrições diagnósticas, ilustrações, comentários taxonômicos, distribuição geográfica e status de conservação para cada espécie.
\end{abstract}

Palavras-chave: briófitas, musgos pleurocárpicos, taxonomia, Mata Atlântica

\begin{abstract}
The genera Lepidopilidium, Lepidopilum, Pilotrichum and Thamniopsis (Pilotrichaceae, Bryophyta) in Rio de Janeiro State, Brazil). The family Pilotrichaceae is well represented in the state of Rio de Janeiro, where 11 genera and 35 species occur. The study includes 17 species of Lepidopilidium (Müll. Hal.), Lepidopilum (Brid.) Brid., Pilotrichum P. Beauv. and Thamniopsis (Mitt.) M. Fleisch. from Rio de Janeiro State. Diagnostic descriptions, illustrations, floristic comments, geographic distribution and conservation status are provided for each species.
\end{abstract}

Key words: bryophytes, pleurocarpous mosses, taxonomy, Atlantic rain forest

\section{Introdução}

A família Pilotrichaceae é bastante diversa na América Tropical, especialmente em ambientes úmidos, sendo representada por 21 gêneros e ca. de 200 espécies (Buck 1998; Gradstein et al. 2001). São conhecidos para o Brasil 14 gêneros e ca. de 140 espécies (Yano 1996). Pilotrichaceae caracteriza-se pela costa dupla (ausente em Crossomitrium), geralmente bem desenvolvida, presença de hialoderme na maior parte das espécies, células alares não diferenciadas e caliptra geralmente pilosa (Buck 1998; Gradstein et al. 2001). Outras características importantes para diversas espécies são a diferenciação entre os filídios laterais e dorsais/ventrais, sendo os dorsais/ventrais simétricos e os laterais assimétricos e a presença de seta ornamentada, que pode ser rugosa, papilosa ou espinhosa.

Embora esta família apresente um grande número de espécies tanto no Brasil quanto no Neotrópico, os problemas na delimitação dos táxons tornam difícil a identificação de grande parte das espécies, que são muito semelhantes em alguns dos gêneros. As publicações que tratam dos táxons desta família (Sehnem 1979; Crosby et al. 1985; Allen 1986; 1990; Schäfer-Verwimp 1989; 1992; Costa 1995; Oliveirae-Silva \& Yano 1998; 2000) são escassas e dispersas, se limitando a levantamentos florísticos de determinadas áreas e revisões taxonômicas de poucos gêneros. Não existe, até o momento, um trabalho que una informações sobre as espécies brasileiras e que auxilie a identificação e delimitação dos seus táxons. Isto evidencia a necessidade urgente da elaboração de um estudo taxonômico para esta importante família de musgos no sudeste do país.

Este trabalho é parte de uma série de estudos realizados com a família Pilotrichaceae no Estado do Rio de Janeiro, tratando das espécies dos gêneros Lepidopilidium, Lepidopilum, Pilotrichum e Thamniopsis, e objetiva fornecer um guia taxonômico que facilite a identificação e delimitação de seus táxons e ampliar o conhecimento da família. Este estudo também representa uma contribuição ao Projeto Flora do Estado do Rio de Janeiro.

\footnotetext{
1 Parte da Dissertação de Mestrado da primeira Autora

2 Univerisidade Federal do Rio de Janeiro, Museu Nacional, Quinta da Boa Vista, 20940-040 São Cristóvão, RJ, Brasil

3 Instituto de Pesquisas Jardim Botânico do Rio de Janeiro, Rua Pacheco Leão 915, 22460-030 Rio de Janeiro, RJ, Brasil

4 Autor para correspondência: celvaz@terra.com.br
} 


\section{Material e métodos}

Inicialmente foi elaborada uma lista preliminar com 12 gêneros e 64 espécies da família Pilotrichaceae citadas para o Estado do Rio de Janeiro, com base nas seguintes publicações: Hornschuch (1840), Müller (1856; 1859; 1898; 1900; 1901), Hampe (1872; 1874a,b; 1877 ; 1879), Hampe \& Geheeb (1881), Brotherus (1894; 1895a,b), Dusén (1903), Herzog (1927), Wijk et al. (1959-1969), Schiffner \& Arnell (1964), Yano (1981; 1989; 1995), Schäfer-Verwimp (1989; 1992), Costa (1995), Oliveira-e-Silva \& Yano (1998; 2000).

Posteriormente, foi realizada a revisão nomenclatural dos táxons com base nos trabalhos de Buck (1987; 1998), Churchill (1988), Crosby et al. (1999), além de exame de material de herbários nacionais e estrangeiros (British Museum - BM, Conservatoire et Jardin Botaniques de la Ville de Gèneve - G, Faculdade de Formação de Professores da Universidade do Estado do Rio de Janeiro - RFFP, Instituto Anchietano de Pesquisas - PACA, Instituto de Botânica - SP, Instituto de Pesquisas Jardim Botânico do Rio de Janeiro - RB, Museu Nacional - R, Herbarium Horti Pisani - PI e Universidade do Estado do Rio de Janeiro - HRJ).

A chave para a identificação dos gêneros e de espécies de Pilotrichaceae foi elaborada com base na literatura e no exame de 65 exemplares das coleções dos herbários acima citados.

A classificação adotada neste trabalho segue a proposta por Buck \& Goffinet (2000); os termos utilizados nas descrições e chaves foram baseados no Glossarium Polyglottum Bryologiae (Magill 1990).

São apresentadas chaves de identificação, descrições diagnósticas, distribuição, status de conservação e ilustrações para os táxons, e os dados apresentados foram baseados nos materiais de diferentes herbários, bem como nos dados da literatura. Além dos sinônimos realizados nesse trabalho, são apresentados também alguns sinônimos recentemente realizados e ainda utilizados como nomes válidos em trabalhos no Brasil.

Para a descrição dos táxons foram consideradas somente as características diagnósticas, tendo como base dados de literatura e de material de herbário. Quando o material estava estéril, a descrição do esporófito foi complementada com dados da literatura.

Os dados da distribuição geográfica, da variação altitudinal, no Rio de Janeiro e no Brasil, e status de conservação no Estado foram retirados de Costa et al. (2005), complementados com dados do material examinado, exceto para Lepidopilum longifolium Hampe e L. surinamense Müll. Hal., que constituem novas ocorrências, respectivamente, para o país e para o Estado do Rio de Janeiro. Neste caso, os dados foram retirados de: Churchill \& Linares (1995) e Churchill (1998), Yano (1995), Yano \& Lisboa (1988), Santos \& Lisboa (2003), Lisboa \& Maciel (1994), Lisboa et al. (1999), Oliveira- e-Silva \& Yano (2000).

\section{Resultados}

Após a revisão da lista de espécies e estudo dos tipos, ocorreu uma redução de $39 \%$ no número total de táxons da família citados para o Estado do Rio de Janeiro. Nesse trabalho, são reconhecidas para a família Pilotrichaceae no Estado do Rio de Janeiro 11 gêneros e 35 espécies e apresentadas as 17 espécies dos gêneros Lepidopilidium, Lepidopilum, Pilotrichum e Thamniopsis ocorrentes no Estado, apresentados três novos sinônimos, citados quatro sinônimos recentemente realizados que ainda são utilizados como nomes válidos no Brasil, e excluídas oito espécies do estudo.

\section{Chave para identificação dos gêneros Lepidopilidium, Lepidopilum, Pilotrichum e Thamniopsis}

1. Margem do filídio com células alongadas

2. Costa conspícua, atingindo $1 / 2$ do compr. da lâmina até quase o ápice do filídio; margem fortemente serreada na parte superior do filídio, com dentes inflados (exceto T. pendula)

\section{Thamniopsis}

2. Costa inconspícua, atingindo 1/3-1/2 do compr. da lâmina; margem serrulada a serreada na parte superior do filídio, sem dentes inflados

1. Margem do filídio sem células alongadas

3. Células do filídio lisas

4. Seta papilosa ou espinhosa; exóstoma com dentes papilosos Lepidopilum (em parte)

4. Seta lisa; exóstoma com dentes estriados transversalmente Lepidopilum (em parte)

3. Células do filídio com papilas no ângulo apical 
5. Filídios elípticos a ovados; ápice cuspidado; costa no ápice divergente e geralmente cristada; margem sem dentes inflados

Pilotrichum

5. Filídios lanceolados; ápice longo-acuminado; costa no ápice paralela, denteada a cristada; margem com dentes inflados e geralmente bífidos Trachyxiphium

\section{Lepidopilidium (Müll. Hal.) Broth.}

Gametófito verde-claro a verde-amarelado ou dourado, caulídio em secção transversal com hialoderme ligeiramente diferenciada, filídios dorsais/ ventrais raramente diferenciados dos laterais, \pm simétricos, margem não diferenciada, costa alcançando 1/3-1/2(-2/3) do compr., células lineares a longoromboidais.

Gênero freqüentemente confundido com Lepidopilum, porém, separado deste pelo esporófito, que apresenta seta lisa, podendo ser fracamente papilosa ou rugosa, nunca espinhosa, e dentes do exóstoma sulcados, transversalmente estriados na $1 / 2$ inferior e papilosos acima (Buck 1998).

Buck (1998) comentou que existem ca. 30 nomes para o gênero, dos quais muitos são possivelmente sinônimos. Segundo Gradstein et al. (2001), esse gênero compreende entre 15-20 espécies, das quais 5-6 ocorrem no Neotrópico. As espécies colonizam ramos e troncos de árvores, sendo a maioria de florestas de terra baixa a sub-montana, entre 0-1.800(-2.800) m (Gradstein et al. 2001). No Estado do Rio de Janeiro o gênero está representado por quatro espécies, ocorrendo sobre troncos de árvores e solo, entre 0-1.780 m.

\section{Chave para as espécies de Lepidopilidium}

1. Filídios ligeiramente diferenciados (observar vários filídos), sendo os laterais assimétricos e os dorsais/ventrais simétricos, oblongos a oblongo-ovados; ápice obtuso

1. Filídios não diferenciados, sendo todos simétricos, oblongo-lanceolados, ovado-lanceolados a lanceolados; ápice agudo a longo-acuminado

2. Filídios com ápice agudo; margem serreada no ápice e inteira em direção à base; costa alcançando ca. $1 / 2$ do compr. 1.2. L. brevisetum

2. Filídios com ápice acuminado a longo-acuminado; margem serrulada a serreada no ápice e serrulada em direção a base; costa alcançando 1/3-1/2 do compr.

3. Filídios com ápice longo-acuminado; margem serreada no ápice; costa alcançando $1 / 2$ do compr.; células apicais lineares 1.1. L. aureo-purpurem

3. Filídios com ápice acuminado; margem serrulada no ápice; costa alcançando $1 / 2$ a $2 / 3$ do compr.; células apicais linear-romboidais 1.3. L. laevisetum

1.1 Lepidopilidium aureo-purpureum (Geh. \& Hampe) Broth., Nat. Pflanzenfam. 1: 944. 1907. Tipo. Brasil, São Paulo, Apiaí, VI-1879, Puiggari 179, 192 (holótipo HBG; isótipo JE).

Fig. 1-6

Lepidopilum aureo-purpureum Mül. Hal. Hedwigia 38: 38. 1899. nom. inval.

Gametófito amarelado a avermelhado, ramificação pinada a bipinada; filídios oblongo-lanceolados a ovadolanceolados; ápice longo-acuminado; margem não diferenciada, serreada acima e serrulada em direção a base; costa inconspícua, alcançando $\pm 1 / 2$ do compr. do filí́dio; células lineares, sendo as medianas mais estreitas e as basais mais alargadas. Esporófito com seta averme- lhada, curta e lisa, cápsula ereta, caliptra pilosa.

Material examinado: BRASIL. Rio de Janeiro: Itatiaia, Caminho para Véu da Noiva, $1.100 \mathrm{~m}$, 21/VII/2005, Costa et al. 4499 (RB).

Material adicional: BRASIL. Santa Catarina: Tubarão, VIII/1890, Ule 94 (R).

A taxonomia de Lepidopilidium aureopurpureum pode causar certa confusão, visto que o basiônimo, Hookeria aureo-purpurea, foi descrito em Hampe \& Geheeb (1881) e, nove anos depois, Müller (1900) descreveu uma espécie com o mesmo nome, atualmente sinônimo de Lepidopilidium brevisetum (Hampe) Broth.

O material de Santa Catarina do herbário R é o original que Müller (1899) utilizou para descrever 
Lepidopilum aureo-purpureum, que, com base no art. 32.1(c) do Código Internacional de Nomenclatura Botânica (Greuter et al. 2003), é um nome inválido. Examinando este material constatou-se que trata-se de Lepidopilidium aureo-purpureum.

Endêmica do Brasil, ocorrendo nos Estados do RJ, SP e SC, entre 0-1.000 m. Citada para o Estado do Rio de Janeiro, por Brotherus (1924), para o Município do Rio de Janeiro, e, no presente trabalho, para Itatiaia. Status de conservação: Ameaçada (EN).

1.2 Lepidopilidium brevisetum (Hampe) Broth., Nat. Pflanzenfam. 1: 944. 1907. Tipo. Brasil, in vicinia urbis Rio de Janeiro, Glaziou s.n. (holótipo BM).

Fig. 7-14

Lepidopilum glabripes Müll. Hal., Hedwigia 39: 278.1900. Material original. Brasil, Rio de Janeiro, Corcovado, XI/1893, Ule 1705 (isótipo R!), nom. inval.

Gametófito irregularmente ramificado; filídios oblongo-lanceolados; ápice agudo; margem não diferenciada, serreada acima e inteira em direção a base; costa inconspícua, \pm desigual, alcançando ca. 1/2 do compr. do filídio; células apicais romboidais, medianas lineares e basais longo-romboidais. Esporófito não observado.

Material examinado: BRASIL. Rio de Janeiro: Casimiro de Abreu, Reserva Biológica de Poço das Antas, Morro do Calcáreo, 8/III/1994, Costa et al. 2002 (RB); Itatiaia, Mont Serrat, 18/VII/1902, Dusén s.n. (dois exemplares, R 82047 e R 14052); Rio de Janeiro, Corcovado, XI/1893, Ule 1705 (R).

Os materiais coletados por Dusén em Itatiaia e depositados no herbário $\mathrm{R}$ foram considerados afins de Lepidopilidium brevisetum, se diferenciando somente quanto à forma e margem dos filídios periqueciais, que são mais longo-acuminados e margem com uma fileira de células alongadas.

Segundo Sehnem (1979), o esporófito apresenta seta lisa e curta.

Endêmica do Brasil, ocorrendo nos Estados do ES, RJ, SP, SC e RS, entre 0-1.200 m. No Rio de Janeiro ocorre nos Municípios de Itatiaia, Rio de Janeiro e Silva Jardim, sendo aqui citado para Casimiro de Abreu, sobre tronco de arbustos e árvores, junto a cursos d'água, entre 0-1.200 m. Status de conservação: Baixo Risco (LR).

1.3 Lepidopilidium laevisetum (Hampe) Broth., Nat. Pflanzenfam. 1: 944. 1907. Tipo. Brasil, Rio de Janeiro, Glaziou 9235 (isótipo BM).

Fig. 15-20
Gametófito irregularmente ramificado; filídios oblongos a oblongo-lanceolados a lanceolados; ápice acuminado; margem serrulada no ápice, não diferenciada; costa inconspícua, alcançando 1/2-2/3 do compr. do filídio, desigual; células apicais e medianas romboidais a lineares, tornando-se mais alargadas em direção a base. Esporófito não observado.

Material examinado: BRASIL. Rio de Janeiro: Nova Friburgo, 1.150 m, 2/V/1988, Costa et al. 586 (RB); ibid. Macaé de Cima, Pedra de São Caetano, 1.500 m, 11/X/1990, Costa et al. 1122 (RB); ibid. São Lourenço, Fazenda Jacarandás, 1.020 m, 29/III/1989, Costa et al. 877 (RB); Magé, Pico do Frade, 1.250-1.350 m, 7/II/1985, Farney et al. 646 (RB); Santa Maria Madalena, Parque Estadual do Desengano, 1780 m, 29/VI/1989, A. Costa et al. 294 (RB).

Segundo Sehnem (1979), o esporófito apresenta seta lisa, cápsula verruculosa e dentes do exóstoma transversalmente estriados e sulcados longitudinalmente.

Ocorre na Venezuela e Brasil, neste último ocorrendo nos Estados do RJ, SP, PR e RS, entre 0-1.500 m. No Rio de Janeiro ocorre no Município de Nova Friburgo, sendo aqui citada para Magé e Santa Maria Madalena, sobre troncos e solo, entre 1.000-1.780 m. Status de conservação: Baixo Risco (LR).

1.4 Lepidopilidium plebejum (Müll. Hal.) Sehnem, Pesquisas Bot. 33: 32. 1979. Tipo. Brasil, Santa Catarina, Tubarão, X-1889, Ule 768; Colonia Blumenau, IX-1888, Ule 473 (síntipo HBG).

Fig. 21-27

Gametófito ramificado, com ramos aplanados; filídios oblongos a oblongo-ovados, ligeiramente diferenciados, os laterais assimétricos, os dorsais/ ventrais simétricos; ápice obtuso; margem levemente diferenciada com células mais alongadas ou, mais raramente, não diferenciada, fracamente serrulada acima e inteira em direção a base; costa inconspícua, alcançando pouco mais da $1 / 2$ do compr. do filídio; células apicais romboidais, medianas longo-romboidais a lineares e basais longo-romboidais a retangulares. Esporófito não observado.

Material examinado: BRASIL. Rio de Janeiro: Nova Friburgo, 11/X/1990, tronco de palmeira, 1.400 m, Costa et al. 1115 (RB).

Em 1979, Sehnem descreveu pela primeira vez o esporófito desta espécie realizando a nova combinação de Lepidopilum para Lepidopilidium, uma vez que a seta é lisa, verrucosa somente no ápice, com cápsula ereta. 

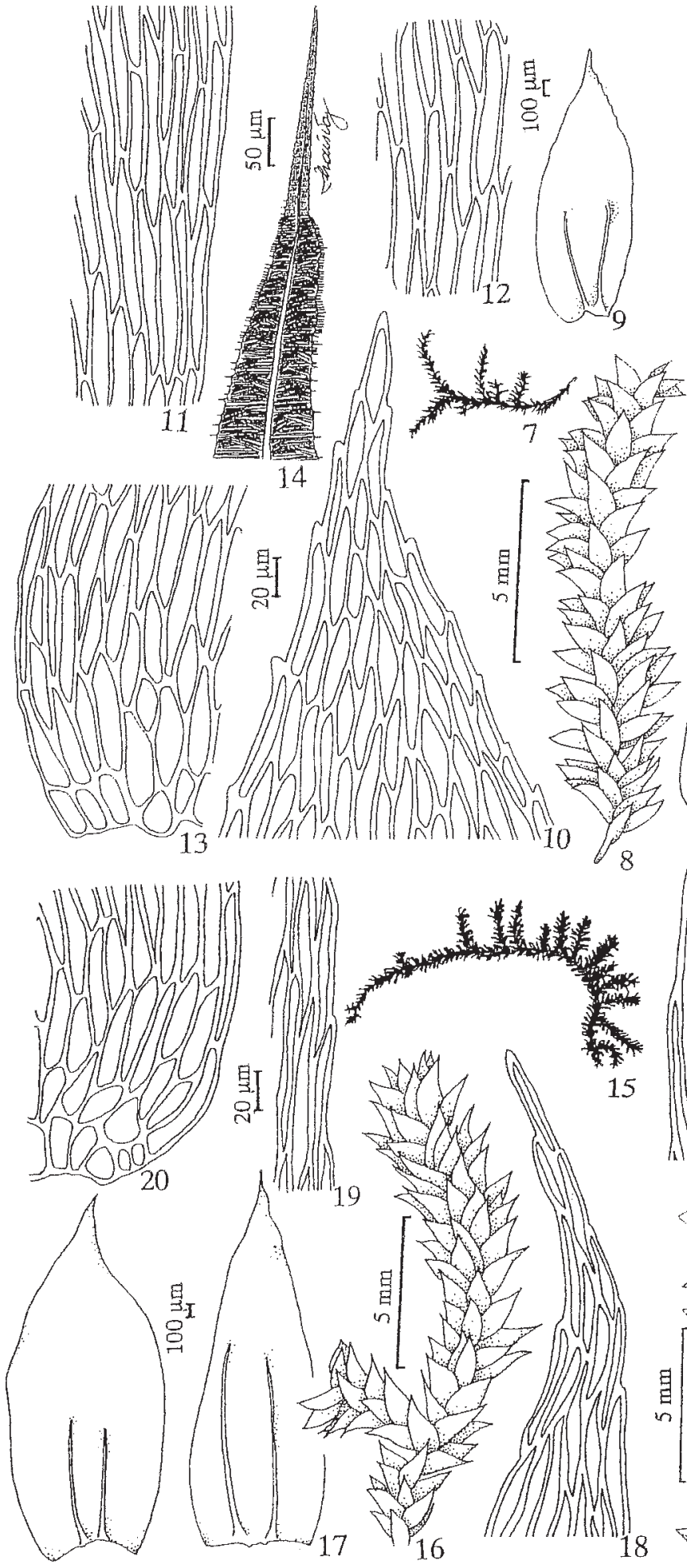
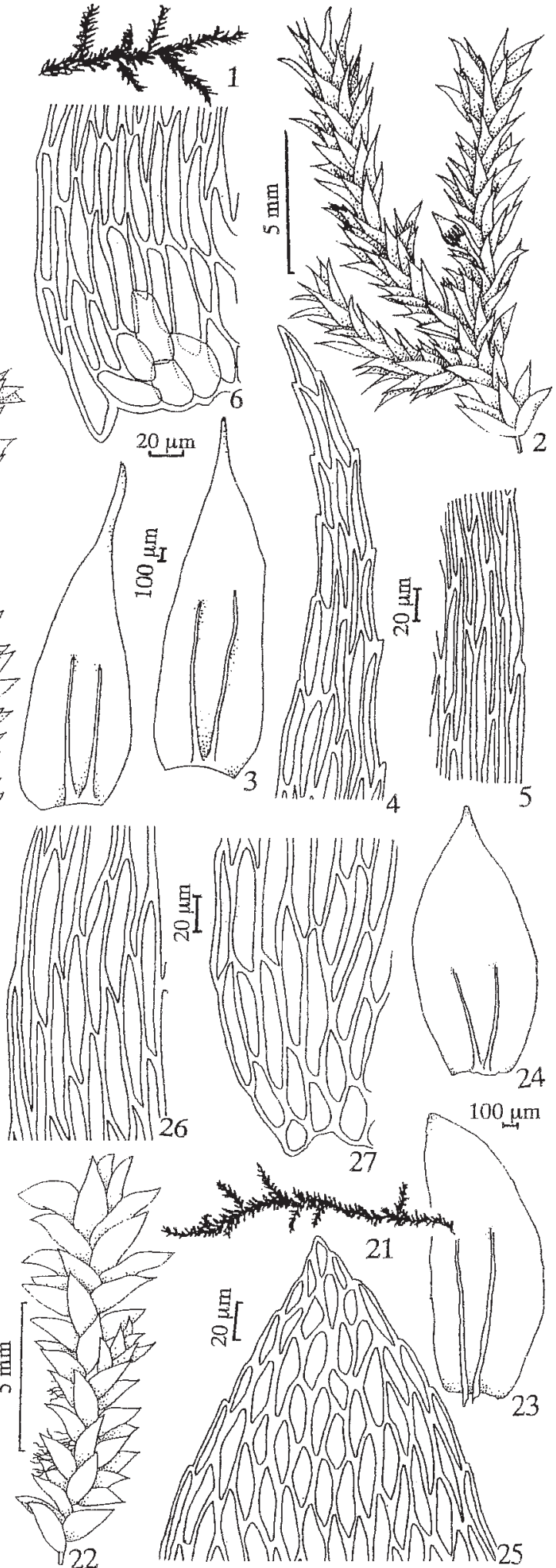

Figuras 1-6. Lepidopilidium aureo-purpureum (Geh. \& Hampe) Broth. 1. Hábito. 2. Detalhe do gametófito com esporófito. 3. Filídios. 4. Ápice do filídio. 5. Células da margem do filídio. 6. Células da base do filídio. Figuras 7-14. Lepidopilidium brevisetum (Hampe) Broth. 7. Hábito. 8. Detalhe do gametófito. 9. Filídio. 10. Ápice do filídio. 11. Células da margem do filído. 12. Células medianas do filídio. 13. Células da base do filídio. 14. Dente do exóstoma sulcado e estriado transversalmente. Figuras 15-20. Lepidopilidium laevisetum (Hampe) Broth. 15. Hábito. 16. Detalhe do gametófito. 17. Filídios. 18. Ápice do filídio. 19. Células da margem do filídio. 20. Células da base do filídio. Figuras 21-27. Lepidopilidium plebejum (Müll. Hal.) Sehnem. 21. Hábito. 22. Detalhe do gametófito. 23. Filídio lateral. 24. Filídio dorsal. 25. Ápice do filídio. 26. Células da margem do filídio. 27. Células da base do filídio. 
Ocorre na América do Sul e no Brasil, nos Estados do RJ, SC e RS, entre 0-1.400 m. No Rio de Janeiro ocorre nos Municípios de Nova Friburgo e Rio Janeiro, sobre tronco e ramo de árvores, junto a cursos d'água, entre 0(?)-1.400 m. Status de conservação: Baixo Risco (LR).

Espécies excluídas do estudo:

Lepidopilidium entodontella (Broth.) Broth. Não foi possível examinar nenhum material dessa espécie oriundo do Estado do Rio de Janeiro o que corrobora a caracterização de Costa et al. (2005), na categoria de Dados Deficientes (DD).

Lepidopilidium nitens (Hornsch.) Broth. - Não foi possível examinar o material tipo do herbário Hamburgense (HBG) ou qualquer outro material dessa espécie oriundo do Estado do Rio de Janeiro.

Lepidopilidium wainioi (Broth.) Broth. - Não foi possível examinar nenhum material dessa espécie oriundo do Estado do Rio de Janeiro o que corrobora a caracterização de Costa et al. (2005), na categoria de Dados Deficientes (DD).

\section{Lepidopilum (Brid.) Brid.}

Gametófito verde-claro a verde-amarelado ou dourado, brilhante, complanado-foliado, caulídio em secção transversal com hialoderme, filídios variando de oblongo-lanceolados a ovados, podendo apresentar diferenciação entre os laterais, assimétricos, e dorsais/ventrais, simétricos. Além disso, a margem do filídio pode ser diferenciada por células mais alongadas. Esporófito com seta curta, papilosa ou espinhosa, cápsula ereta, dentes do exóstoma densamente papilosos, caliptra campanulada ou mitrada e pilosa.

Lepidopilum apresenta considerável variação, tanto no gametófito quanto no esporófito (Gradstein et al. 2001). Segundo Buck (1998), se relaciona com Crossomitrium e Lepidopilidium, do qual é praticamente impossível ser separado somente através das características do gametófito. Difere deste último somente por características do esporófito, que em Lepidopilum apresenta seta papilosa, espinhosa ou rugosa e dentes do exóstoma papilosos.

Gênero neotropical que compreende ca. 40 espécies, ocorrendo sobre troncos e ramos de árvores e arbustos, também observado em bambu e lianas, raramente sobre pedras de córregos; em florestas de terra baixa a alto montana, entre 0-3.700 m (Gradstein et al. 2001). No Estado do Rio de Janeiro está representado por sete espécies, ocorrendo sobre troncos de árvores, rochas e, menos freqüentes sobre folhas, podendo ser associados a cursos d'água, entre $0-1.300 \mathrm{~m}$.

\section{Chave para as espécies de Lepidopilum}

1. Filídios com margem diferenciada com células alongadas e lineares 2.7. L. surinamense

1. Filídios sem margem diferenciada com células alongadas e lineares

2. Filídios laterais e dorsais/ventrais diferenciados, sendo os laterais assimétricos e os dorsais/ ventrais simétricos

3. Filídios lanceolados, 4-5 vezes mais longos do que largos

4. Ápice do filídio acuminado, com células romboidais 2.3. L. muelleri

4. Ápice do filídio longo-acuminado, com células lineares 2.6. L. subsubulatum

3. Filídios ovados a oblongo-lanceolados, 2-3 vezes mais longos do que largos

5. Filídios ovados; ápice agudo 2.4. L. ovalifolium

5. Filídios oblongo-lanceolados; ápice acuminado

6. Margem do filídio serreada no ápice e serrulada em direção à base ..... 2.5. L. scabrisetum

6. Margem do filídio serrulada no ápice e inteira a sinuada em direção à base 2.1. L. caudicaule

2. Filídios laterais e dorsais/ventrais não diferenciados, sendo todos simétricos 2.2. L. longifolium

2.1 Lepidopilum caudicaule Müll. Hal., Hedwigia 39: 272. 1900. Tipo. Brasil, Rio de Janeiro, Serra dos Órgãos, XII-1891, Ule 1249 (holótipo HBG; isótipo R!).

Fig. 28-35

Gametófito irregularmente ramificado; filídios diferenciados, sendo os laterais assimétricos e os dorsais/ventrais simétricos, oblongo-lanceolados; ápice acuminado; margem não diferenciada, fracamente serrulada acima, inteira a sinuada em direção a base; costa inconspícua, ligeiramente desigual, divergente, alcançando 1/3 do compr. do filídio; células apicais e medianas linear-romboidais, basais longo-romboidais 
a retangulares. Esporófito com seta papilosa, exceto próximo a base e no ápice, cápsula ereta. Caliptra não observada.

Material adicional: BRASIL. Santa Catarina: Bom Retiro, campo dos Padres, 1.700 m, 15/I/1957, Sehnem 6993 (PACA).

O material de Lepidopilum caudicaule examinado apresenta filídios laterais assimétricos e os dorsais/ventrais simétricos, entretanto, no material do herbário $\mathrm{R}$ a assimetria dos filídios laterais é menos evidente. Sehnem (1979) descreveu a caliptra como pouco pilosa.

Müller (1900), apesar de ter descrito esta espécie no gênero Lepidopilum, já indicava a possibilidade de ser Lepidopilidium, pois o material encontrava-se estéril. Em 1907, Brotherus transferiu o táxon para Lepidopilidium, como é aceito em Crosby et al. (1999) e Costa et al. (2005). Sehnem (1979) manteve Lepidopilum caudicaule, uma vez que o material de Santa Catarina (Sehnem 6993, PACA) combina com a descrição de Müller (1900), apresentando seta ornamentada característica do gênero Lepidopilum.

$\mathrm{O}$ material do herbário $\mathrm{R}$ é possivelmente um isótipo, já que apresenta os mesmos dados da coleção tipo do herbário HBG (não examinada) para coletor, número de coleta e data. Examinando este material corrobora-se as observações de Sehnem (1979), quanto a pertencer ao gênero Lepidopilum.

Endêmica do Brasil, ocorrendo nos Estados do RJ e SC, entre 1.200-1.700 m. Para o Rio de Janeiro é citada por Müller (1900) e Bartram (1954), para o Município de Teresópolis, ocorrendo sobre rocha, acima de $800 \mathrm{~m}$. Status de conservação: Vulnerável (VU - por ser endêmica do Brasil, ocorrendo nos Estados de SC e RJ, entre 1.200-1.700 m, sendo as duas últimas citações feitas por Sehnem, em 1979, há 25 anos).

2.2 Lepidopilum longifolium Hampe, Ann. Sci. Nat. Bot. V, 4: 365. 1865. Tipo. Colômbia, Tequendama, Escaleros $2.500 \mathrm{~m}$, Lindg s.n. (lectótipo BM, designado por Churchill 1988).

Fig. 36-43

Gametófito irregularmente ramificado; filídios sem diferenciação entre os laterais, dorsais/ventrais, lanceolados a oblongo-lanceolados, sendo todos simétricos; ápice acuminado a longo-acuminado; margem não diferenciada, serrulada a serreada acima e inteira em direção a base; costa inconspícua, gradualmente desigual, divergente, alcançando 1/3-1/2 do compr. do filí́dio; células apicais e medianas lineares, basais longo-retangulares. Esporófito com seta espinhosa, cápsula ereta. Caliptra não observada.

Material examinado: BRASIL. Rio de Janeiro: Itatiaia, Caminho para o Véu da Noiva, $1.100 \mathrm{~m}$, 15/II/1994, Andrade s.n. (RB 382306); ibid. Maromba, $1.100 \mathrm{~m}, 17 / \mathrm{IX} / 1955$, Fidalgo \& Kauffmann Fidalgo Eg-19 (RB).

Churchill (1988), descreve os filídios periqueciais como longo-lanceolados ou longo-subulados, com ápice longo-acuminado e esporófito com seta vermelha escura, fortemente espinhosa, raramente papilosa. Este autor comenta ainda que a espécie pode variar com relação ao hábito e forma do filídio, podendo ser mais estreito ou mais largo, simétrico ou ligeiramente assimétrico, com margem não diferenciada e inteira. O material do herbário RB se encontra na variação observada por Churchill (1988), apresentando filídio lanceolado a oblongo-lanceolado, com margem não diferenciada. Churchill (1988) descreve a caliptra é mitrada-campanulada e pilosa.

Segundo Churchill \& Linares (1995), esta espécie apresenta ampla distribuição no Neotrópico, ocorrendo freqüentemente em áreas de média a alta altitude, desde o México, América Central, Antilhas (baixa altitude) e Andes tropicais. Esta espécie é citada aqui pela primeira vez para o Brasil, onde ocorre no Estado do Rio de Janeiro, Município de Itatiaia, sobre troncos de árvores, ca. 1.100 m. Status de conservação: Vulnerável (VU - conhecida no Brasil somente por duas coleções provenientes do PARNA-Itatiaia, ambas realizadas em áreas que sofrem forte pressão pelo turismo, Cachoeira da Maromba e do Véu de Noiva).

2.3 Lepidopilum muelleri (Hampe) Spruce, Ann. Sci. Nat. Bot., 4: 365. 1865. Tipo. Venezuela, Moritz s.n. (isótipos BM, S).

Fig. 44-53

Lepidopilum pringlei Cardot, Revue Bryologique 37: 51. 1910. Tipo. Mexico, Vera Cruz, 25-VI-1908, Pringle 10499 (lectótipo PC, designado por Churchill 1988; isolectótipos F, L, NY, US). syn. fide Churchill (1988).

Gametófito irregularmente ramificado; filídios diferenciados, os laterais assimétricos e os dorsais/ ventrais simétricos, lanceolados a oblongo-lanceolados; ápice acuminado a longo-acuminado; margem não diferenciada, serrulada a serreada no 1/3(-1/2) superior; costa inconspícua, gradualmente divergente, alcançando $1 / 3$ do compr. do filídio; células apicais romboidais, medianas longo-romboidais e basais longoromboidais a longo-retangulares. Filídios periqueciais lanceolados a linear-lanceolados, com ápice longo- 
acuminado, sem costa. Esporófito com seta espinhosa, mais raramente papilosa, avermelhada, cápsula ereta e caliptra mitrada, densamente pilosa.

Material examinado: BRASIL. Rio de Janeiro: Itatiaia, Mont Serrat, 900 m, 11/V/1902 Dusén 199 (R); ibid. XII/1924, Occhioni s.n. (RB 174406); ibid. Mauá, 8/II/1925, Bandeira s.n. (RB 92739); Nova Friburgo, Morro do Curuzu, 1.300 m, 15/VII/1987, Costa et al. 303 (RB); ibid. Theodoro de Oliveira, 1.100 m, 27/III/1989, Costa et al. 740 (RB); ibid. São Lourenço, Fazenda Jacarandás, 1.020 m, 29/III/1989, Costa et al. 877 (RB); Petrópolis, Pedreira do Quitandinha, 16/II/1924, Bandeira s.n. (RB 174403); ibid. 17/II/1924, Bandeira s.n. (RB 174401).

Material adicional: BRASIL. Minas Gerais: Serra de Gramma, 1.000 m, 21/IV/1925, Chase s.n. (RB 174402).

Segundo Churchill (1988), esta espécie apresenta polimorfia e os limites morfológicos não são bem definidos, variando consideravelmente em relação ao gametófito, tanto no tamanho quanto na forma dos filídios, o que foi observado nos materiais do herbário $\mathrm{RB}$.

Lepidopilum muelleri é muito semelhante a L. subsubulatum, sendo difíceis de diferenciar, visto que apresentam semelhança quanto a forma dos filídios, filídios periqueciais e esporófito. Os táxons se diferenciam somente quanto ao ápice do filídio, que em L. muelleri é acuminado e com células romboidaissinuadas, enquanto que em L. subsubulatum é longoacuminado e com células lineares. Churchill (1988), na revisão do gênero, já comentava a dificuldade em separar estas duas espécies, porém preferiu não sinonimizá-las, posição adotada neste estudo.

Ocorre no México, Ilha dos Cocos (Costa Rica) e Brasil, onde é citado para o Estado do Rio de Janeiro, Município de Nova Friburgo, sendo aqui citada para Itatiaia, sobre troncos de árvore, troncos caídos e rocha, entre 800-1.300 m. Status de conservação: Baixo Risco (LR).

2.4 Lepidopilum ovalifolium (Duby) Broth., Bih. Kongl. Svenska Vetensk.-Akad. Handl., 3: 34. 1895. Tipo. Bolivia, Cochabamba, Incacorral, ca. 2.200 m, I-1908, Herzog s.n. (holótipo B).

Fig. 54-61

Gametófito irregularmente ramificado; filídios diferenciados, os laterais assimétricos e os dorsais/ ventrais simétricos, ovados; ápice agudo a curtoacuminado; margem não diferenciada, serreada na metade superior; costa inconspícua, divergente, alcançando $1 / 3$ do comprimento do filídio; células apicais romboidais, medianas lineares e basais longoromboidais a longo-retangulares. Esporófito não observado.

Material examinado: BRASIL. Rio de Janeiro: Itatiaia, caminho para o Véu da Noiva, $1.100 \mathrm{~m}$, 15/II/1994, Andrade s.n. (RB 382347); Nova Friburgo, estrada para Salinas, 10/XII/1987, Costa et al. 455 (RB).

Material adicional: BRASIL. Rio Grande do Sul: Caxias do Sul, Vila Oliva, 650 m, 12/I/1947, Sehnem 2644 (RB).

Destaca-se das demais espécies de Lepidopilum do Rio de Janeiro pelos filídios ovados com ápice agudo.

Endêmica do Brasil, ocorrendo nos Estados do RJ, SP, SC e RS, entre 0-800 m. No Rio de Janeiro ocorre no Município de Nova Friburgo, sendo aqui citado para Itatiaia, sobre solo e rocha, junto a cursos d'água, acima de 800 m. Status de conservação: Baixo Risco (LR).

2.5 Lepidopilum scabrisetum (Schwägr.) Steere, Bryologist 51: 140. 1948. Tipo. Guiana, Richard s.n. (holótipo G; isótipos BM, NY).

Fig. 62-71

Gametófito densa e irregularmente ramificado; filídios diferenciados, sendo os laterais assimétricos e os dorsais/ventrais simétricos, oblongo-lanceolados; ápice acuminado; margem não diferenciada, serreada acima e serrulada em direção à base; costa inconspícua, desigual, gradualmente divergente, alcançando 1/3-1/2 do compr. do filídio; células linearromboidais, tornando-se retangulares na base. Esporófito com seta papilosa a espinhosa, a ornamentação diminui em direção às extremidades, avermelhada, cápsula ereta. Caliptra não observada.

Material examinado: BRASIL. Rio de Janeiro: Parati, Km 204 da Rodovia Rio-Santos, 80 m, 8/V/1991, Costa et al. 1479 (RB); ibid. Caminho do Sono para o Saco do Mamanguá, 19/X/1990, Costa et al. 1245 (RB); ibid. Ponta Negra, picada para Jamanta, 40 m, 10/V/1991, Costa et al. 1537 (RB); Rio de Janeiro, Tijuca, Ule s.n. (R 82044).

Neste táxon foi observada variação no tipo de ornamentação da seta que pode se apresentar papilosa a espinhosa. Churchill (1988) descreveu a caliptra como mitrada-campanulada, esparsa a densamente pilosa.

Apresenta distribuição neotropical, ocorrendo no Brasil nos Estados do RR, AP, PA, AM, PE, MG, RJ, SC e RS, entre 0-1.700 m. No Rio de Janeiro ocorre nos Municípios de Casimiro de Abreu, Magé, Niterói, 

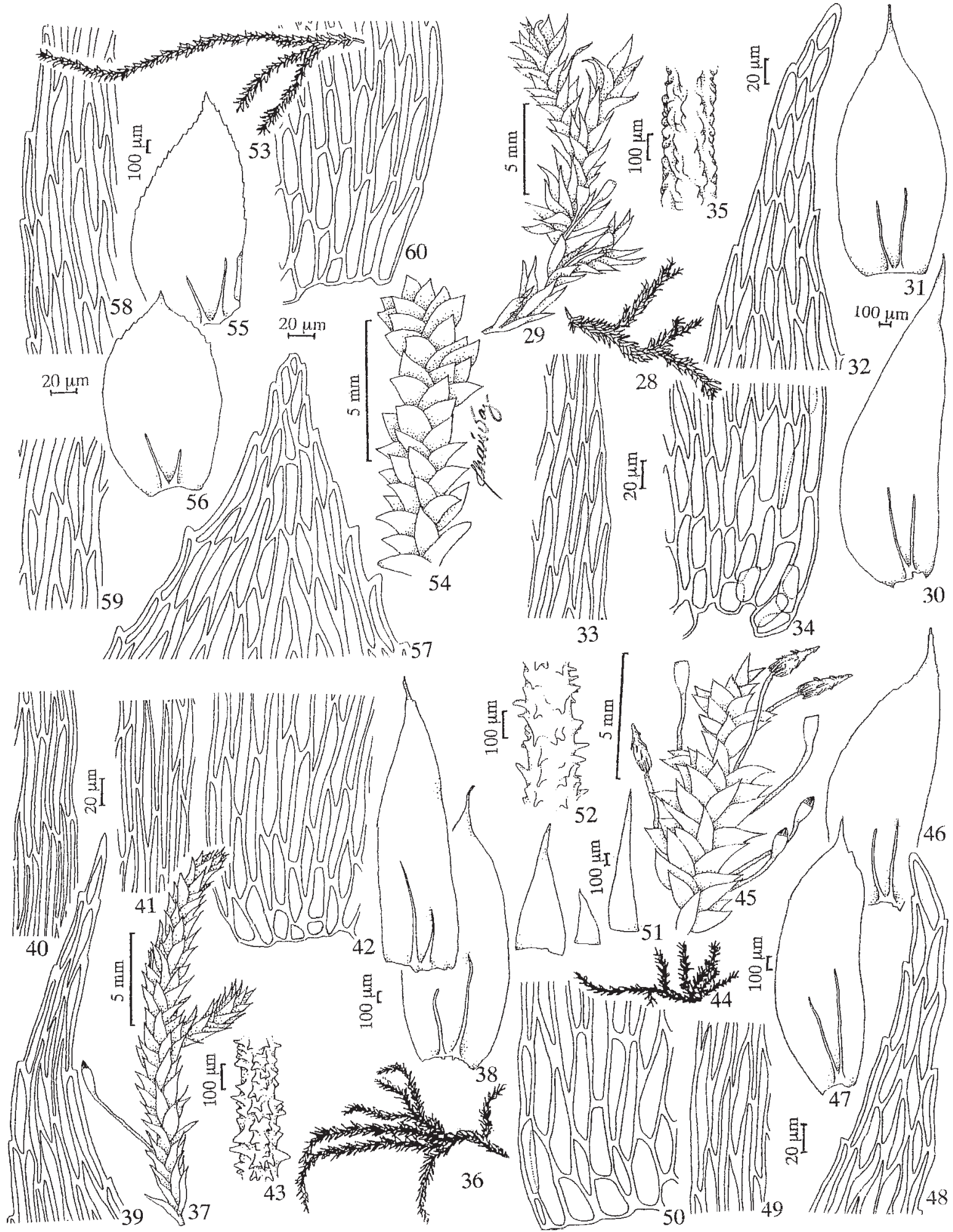

Figuras 28-35. Lepidopilum caudicaule Müll. Hal. 28. Hábito. 29. Detalhe do gametófito com esporófito. 30. Filídio lateral. 31 . Filídio dorsal. 32. Ápice do filídio. 33. Células da margem do filídio. 34. Células da base do filídio. 35. Detalhe da seta papilosa. Figuras 36-43. Lepidopilum longifolium Hampe. 36. Hábito. 37. Detalhe do gametófito com esporófito. 38. Filídios. 39. Ápice do filídio. 40. Células da margem do filídio. 41. Células medianas do filídio. 42. Células da base do filídio. 43. Detalhe da seta espinhosa. Figuras 44-52. Lepidopilidium muelleri (Hampe) Spruce. 44. Hábito. 45. Detalhe do gametófito com esporófito. 46. Filídio lateral. 47. Filídio dorsal. 48. Ápice do filídio. 49. Células da margem do filídio. 50. Células da base do filídio. 51. Filídios periqueciais. 52. Detalhe da seta espinhosa. Figuras 53-60. Lepidopilum ovalifolium (Duby) Broth. 53. Hábito. 54. Detalhe do gametófito. 55. Filídio lateral. 56. Filídio dorsal. 57. Ápice do filídio. 58. Células da margem do filídio. 59. Células medianas do filídio. 60. Células da base do filídio. 
Nova Friburgo e Parati, sendo aqui citada para Rio de Janeiro, geralmente sobre rochas, troncos e ramos, entre 0-1.100 m. Status de conservação: Baixo Risco (LR).

2.6 Lepidopilum subsubulatum Geh. \& Hampe, Vidensk. Meddel. Dansk. Naturhist. Foren. Kjøbenhavn, ser. 4, 1: 123. 1879. Tipo. Brasil, São Paulo, Apiaí, 1879, Puiggari 53 (lectótipo G!, designado por Churchill 1988; isolectótipo H-BR).

Fig. 72-82

Callicostella daltoniaecarpa (Müll. Hal.) Broth., Nat. Pflanzenfam. 1: 938. 1907. Tipo. Brasil, Itatiaia, Ule 1866 (isótipo R!); syn. nov.

Lepidopilum flavescens Geh. \& Hampe, Vidensk. Meddel. Dansk. Naturhist. Foren. Kjøbenhavn, ser. 4, 1: 124. 1879. Tipo. Brasil, São Paulo, Apiaí, Puiggari 53 (holótipo G!); syn. nov.

Lepidopilum pycnodictyon Müll. Hal., Hedwigia 39: 271. 1900. Tipo. Brasil, Santa Catarina, Serra Geral, I-1890, Ule 862 (lectótipo H-BR, designado por Churchill 1988). syn. fide Churchill (1988).

Lepidopilum subaurifolium Geh. \& Hampe, Flora 64: 405. 1881. Tipo. Brasil, Rio de Janeiro, 1880, Glaziou 11736 (holótipo G; isótipos H-BR, NY). syn. fide Churchill (1988).

Lepidopilum stenodictyon Sehnem, Pesquisas Bot. 33: 53. 1979. Tipo. Brasil, Rio de Janeiro, Nova Friburgo, 5-V-1957, Sehnem 7714 (lectótipo PACA, designado por Churchill 1988; isolectótipo NY). syn. fide Churchill (1988).

Gametófito irregularmente ramificado; filídios diferenciados, os laterais, assimétricos e os dorsais/ ventrais, simétricos, lanceolados a oblongo-lanceolados; ápice estreitamente longo-acuminado; margem não diferenciada, serrulada a serreada no terço superior; costa inconspícua, gradualmente desigual, divergente, alcançando pouco mais de $1 / 3$ do compr. do filídio; células lineares, sendo as basais um pouco mais largas e retangulares. Filídios periqueciais lanceolados, com ápice longo acuminado, sem costa. Esporófito com seta toda papilosa ou fortemente espinhosa, castanha, cápsula ereta a sub-ereta, caliptra mitrada, densamente pilosa.

Material examinado: BRASIL. Rio de Janeiro: Itatiaia, Mauá, 8/II/1925, Bandeira s.n. (RB 174405); Nova Friburgo, Duas Pedras, 1.200 m, 23/I/1955, Sehnem 6756 (PACA); ibid. Macaé de Cima, 1.040 m, 3/V/1988, Costa et al. 599 (RB); Petrópolis, Araras, base da Pedra Maria Comprida, 23/III/1968, Sucre
2552 e Braga 393 (RB); Rio de Janeiro, Corcovado, 21/XI/1891, Ule 1250 (R).

Material adicional: BRASIL. Santa Catarina: Campo dos Padres, Bom Retiro, 1.700 m, 18/I/1957, Sehnem 7090, 7090a (como L. flavescens) (PACA); Ilha de Santa Catarina, Morro do Antão, 250 m, 3/I/1948, Sehnem 3203 (como L. flavescens, PACA).

Foi observada no material examinado uma variação na ornamentação da seta, de papilosa a fortemente espinhosa. Entretanto, Churchill (1988) descreveu a seta como toda papilosa, exceto na base, onde é espinhosa.

Lepidopilum subsubulatum é muito semelhante a L. muelleri, sendo difícil a separação destas duas espécies (ver comentários desta última).

Endêmica do Brasil, ocorrendo nos Estados de MG, RJ, SP, SC e RS, entre 0-2.000 m. No Rio de Janeiro ocorre nos Municípios de Itatiaia e Nova Friburgo, sendo aqui citado para Rio de Janeiro e Petrópolis, ocorrendo como epífila, ou sobre rochas, troncos e ramos de árvores, entre 600-1.300 m. Status de conservação: Baixo Risco (LR).

2.7 Lepidopilum surinamense Müll. Hal., Linnaea 21: 193. 1848. Tipo. Suriname, Mariepaston, Kegel 1406 (isótipo H-BR, JE).

Fig. 83-90

Gametófito verde-escuro, com ramificação pinada a bipinada; filídios não diferenciados, contorcidos quando secos, oblongos a elípticos; ápice agudo a curtoacuminado; margem diferenciada por 1-2 fileiras de células alongadas e lineares, serrulada; costa divergente, alcançando 1/2 do compr. do filídio; células apicais romboidais, medianas ligeiramente mais longas e basais retangulares. Filídios periqueciais lanceolados, com ápice longo-acuminado, com costa dupla. Esporófito não observado.

Material examinado: BRASIL. Rio de Janeiro: Angra dos Reis, Ilha Grande, caminho para Praia de Palmas, 21/II/1995, Oliveira-e-Silva 2855 (HRJ); ibid. caminho para Caxadaço, $160 \mathrm{~m}, 18 / \mathrm{IV} / 1995$, Oliveira-e-Silva 4080 (HRJ); ibid. caminho para Parnaióca, 20 m, 16/V/1995, Oliveira-e-Silva 4133 (HRJ); ibid. 140 m, 16/V/1995, Oliveira-e-Silva 4190 (HRJ); Mangaratiba, Km 54 da Rodovia Rio-Santos, Reserva Ecológica Rio das Pedras, 13/V/1993, Oliveira-e-Silva 484 (HRJ); ibid. 22/VII/1993, Oliveira-e-Silva 589 (HRJ).

Diferencia-se das demais espécies estudadas por apresentar filídios com margem diferenciada por células alongadas e lineares e filídios periqueciais com costa 
dupla. Segundo Churchill (1988), a seta é lisa ou rugosa, cápsula ereta a sub-ereta e caliptra curtamente mitrada-campanulada, pilosa.

As ocorrências de L. scabrisetum em Costa et al. (2005) para os Municípios de Angra e Mangaratiba referem-se aos materiais citados por Oliveira-e-Silva \& Yano (2000). O exame dessas coleções revelou que esses exemplares foram erroneamente identificados e pertencem a $L$. surinamense.

Apresenta distribuição neotropical, ocorrendo no Brasil nos Estados do AP, PA AM, RO e RJ, entre 0-1.110 m. No Rio de Janeiro ocorre nos Municípios de Angra dos Reis e Mangaratiba, sobre ramos de árvores, lianas, base de tronco de árvores, ocasionalmente sobre solo e raramente sobre troncos caídos ou folhas vivas, ocorrendo ao nível do mar. Status de conservação: Baixo Risco (LR).

Espécies excluídas do estudo:

Lepidopilum affine Müll. Hal. - Apesar de ser citada para os Municípios de Itatiaia, por Brotherus (1924) e Müller (1898), e Teresópolis, por Bartram (1954), até o presente momento não foi possível confirmar a presença desse táxon no Estado.

Lepidopilum beyrichii Hampe - Trata-se possivelmente de um sinônimo ou nome inválido, visto que não consta na lista de espécies de musgos do mundo (Crosby et al. 1999).

Lepidopilum curvirameum (Müll. Hal.) Paris - Crosby et al. (1999) classificaram esta espécie como insuficientemente conhecida, porque nenhuma informação foi publicada posterior a 1962. Até o momento não foi confirmar a presença desse táxon no Estado.

Lepidopilum glaziovii Hampe - Considerada por Crosby et al. (1999) como insuficientemente conhecida do ponto de vista taxonômico, possivelmente trata-se de um sinônimo. Citada por Hampe (1879) sem localidade para o Rio de Janeiro.

\section{Pilotrichum P. Beauv.}

Gametófito frondoso, com ramificação pinada, bipinada ou tripinada, o que facilmente o difere dos demais gêneros da família, caulídio em secção transversal sem hialoderme, filídios com costa conspícua, ápice cristado na superfície dorsal, células com papila no ângulo apical e seta curta, quase sempre duas vezes o tamanho da cápsula (Gradstein et al. 2001).

Gênero neotropical com ca. 20 espécies e diversidade centrada nas Antilhas, ocorrendo sobre troncos e ramos de árvores, em florestas de terra baixa a sub-montana, entre 0-2.460 m (Gradstein et al. 2001). No Estado do Rio de Janeiro está representado por uma espécie, ocorrendo sobre troncos de árvores e rocha, $0-800 \mathrm{~m}$ de altitude.

3.1 Pilotrichum evanescens (Müll. Hal.) Crosby, Bryologist 72: 326. 1969. Tipo. Suriname, Paramaribo, Kegel 742 (lectótipo GOET, designado por Crosby 1969).

Fig. 91-101

Gametófito verde-escuro a verde-claro, ramificação bipinada a tripinada; filídios elípticos a ovados, freqüentemente côncavos; ápice cuspidado; margem toda serrulada, às vezes inteira em direção a base; costa desigual, divergente no ápice, alcançando 3/4 do compr. do filídio, ápice geralmente cristado, propágulos unisseriados quase sempre presentes na base; células apicais e medianas romboidais, com papila no ângulo apical, basais mais alongadas e com pontuações. Filídios periqueciais lanceolados a oblongolanceolados; costa dupla, alcançando $1 / 2$ ou mais do compr. do filídio, desigual; ápice agudo a gradualmente acuminado. Esporófito com seta curta, rugosa por todo o seu comprimento, cápsula ereta. Caliptra não observada.

Material examinado: BRASIL. Rio de Janeiro: Santa Maria Madalena, Parque Estadual do Desengano, trilha para Morumbeca do Imbe, 15/VI/2000, MCF dos Santos 556 (RFFP).

Material adicional: BRASIL. Amazonas: Manaus, Reserva Duke (INPA), $26 \mathrm{~km}$ de Manaus, 16/VII/1996, Costa et al. 3139 (RB).

Segundo Buck (1998), a caliptra é mitrada, lobada na base, pilosa e rugosa acima.

Buck (1998) descreveu a costa do filídio como não cristada ou com uma pequena crista, formada por uma única célula de altura. Florschütz-de-Waard (1986) descreveu a costa como lisa ou com pequenos dentes no ápice. Entretanto, o material examinado apresenta costa cristada, formada por mais de uma célula de altura.

Buck (1998) descreveu os filídios periqueciais como ecostados ou com costa dupla e curta. No material examinado os filídios periqueciais apresentam costa dupla alcançando 1/2 ou mais do comprimento.

Apresenta distribuição neotropical e no Brasil ocorre nos Estados do RR, PA, AM, PE, BA, MG, RJ, SP, PR e SC, entre 0-1.200 m. No Rio de Janeiro ocorre nos Municípios de Magé, Mangaratiba, Niterói, sendo aqui citado para Santa Maria Madalena, sobre tronco 

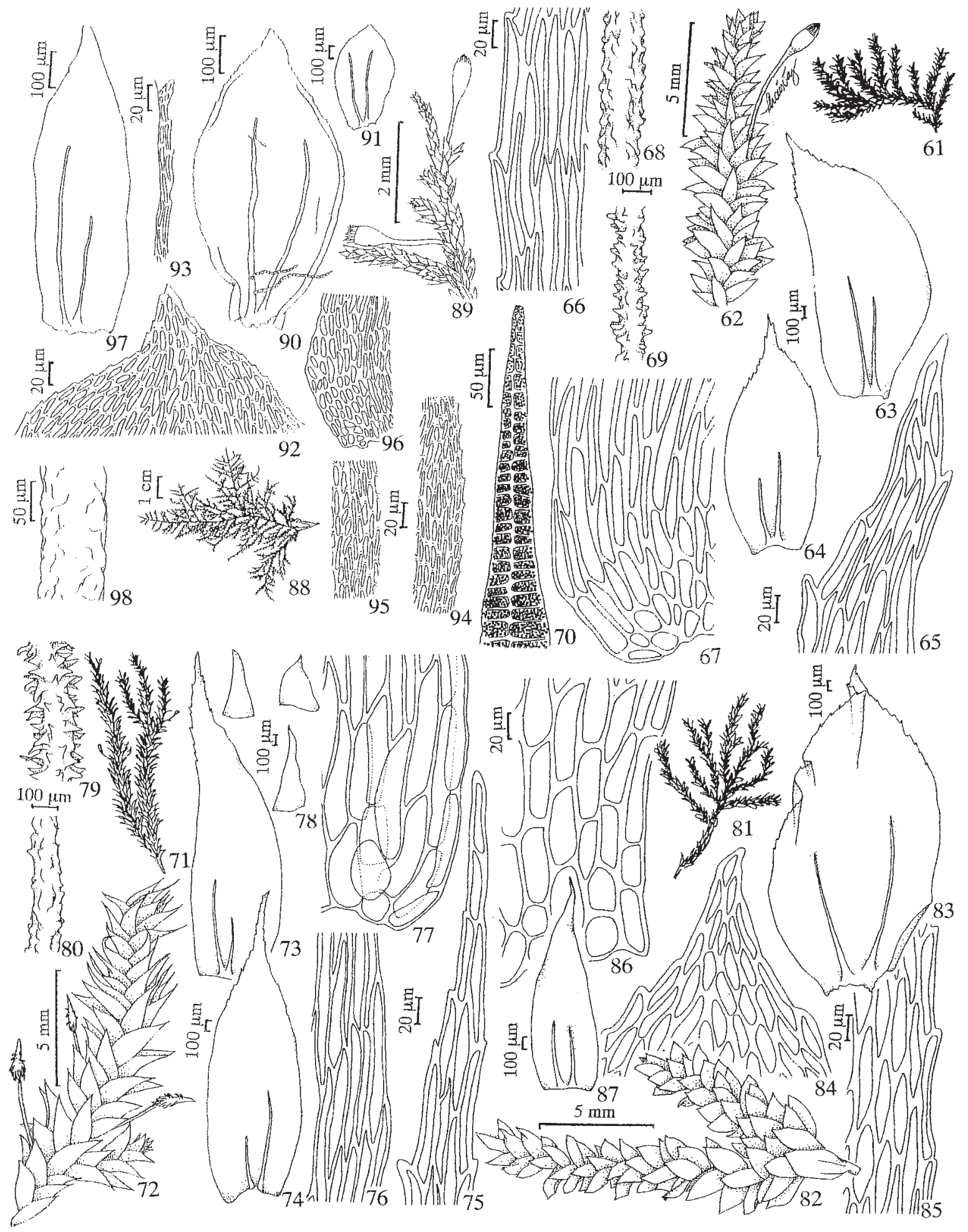

Figuras 61-70. Lepidopilum scabrisetum (Schwägr.) Steere. 61. Hábito. 62. Detalhe do gametófito com esporófito. 63. Filídio lateral. 64. Filídio dorsal. 65. Ápice do filídio. 66. Células da margem do filídio. 67. Células da base do filídio. 68. Detalhe da seta papilosa. 69. Detalhe da seta espinhosa. 70. Dente do exóstoma papiloso. Figuras 71-80. Lepidopilum subsubulatum Geh. \& Hampe. 71. Hábito. 72. Detalhe do gametófito com esporófito. 73. Filídio lateral. 74. Filídio dorsal. 75. Ápice do filídio. 76. Células da margem do filídio. 77. Células da base do filídio. 78. Filídios periqueciais. 79. Detalhe da seta espinhosa. 80. Detalhe da seta papilosa. Figuras 81-87. Lepidopilum surinamense Müll. Hal. 81. Hábito. 82. Detalhe do gametófito. 83. Filídio. 84. Ápice do filídio. 85. Células da margem do filídio. 86. Células da base do filídio. 87. Filídio periquecial. Figuras 88-98. Pilotrichum evanescens (Müll. Hal.) Müll. Hal. 88. Hábito. 89. Detalhe do gametófito com esporófito. 90. Filídio. 91. Forma do filídio. 92. Ápice do filídio. 93. Ápice da costa. 94. Células da margem do filídio. 95. Células medianas do filídio. 96. Células da base do filídio. 97. Filídio periquecial. 98. Detalhe da seta rugosa. 
caído, 0-800 m. Status de conservação: Baixo Risco (LR).

\section{Thamniopsis (Mitt.) M. Fleisch.}

Gametófito irregularmente ramificado a pinado, caulídio em seção transversal com hialoderme bem desenvolvida, filídios com margem geralmente serreada, com dentes inflados, células lisas e areolação heterogênea, sendo as células basais maiores que as apicais e medianas.

Buck (1987) transferiu muitas espécies de Hookeriopsis para Thamniopsis, onde Hookeriopsis se diferencia da última por apresentar caulídio em secção transversal sem hialoderme desenvolvida, filídios com margem não diferenciada, inteira a serrulada, sem dentes inflados, costa inconspícua e curta e areolação homogênea.

Gênero pantropical com 15 espécies, sendo 10 no Neotrópico, ocorrendo sobre solo, rochas e troncos em decomposição, em florestas de terra baixa a submontana, raramente alto montana, entre 0-3.400 m (Gradstein et al. 2001). No Rio de Janeiro está representado por cinco espécies, ocorrendo sobre tronco em decomposição, rochas, solo e raiz, freqüentemente associados a cursos d'água, entre $0-1.200 \mathrm{~m}$.

Chave para as espécies de Thamniopsis

1. Filídios com margem inteira

4.3. T. pendula

1. Filídios com margem serreada ou serrulada

2. Filídios laterais e dorsais/ventrais diferenciados, sendo os laterais assimétricos e os dorsais ventrais simétricos; ápice arredondado a obtuso; células da lâmina hexagonais ( $\pm 1-2: 1)$

4.1. T. incurva

2. Filídios laterais e dorsais/ventrais não diferenciados, sendo todos simétricos; ápice agudo, acuminado, aristado ou obtuso; células da lâmina romboidais a longo-romboidais ( \pm 4-6:1)

3. Filídios sempre conspicuamente ondulados; ápice longo-acuminado; ápice da costa denteado

4.5. T. undata

3. Filídios raramente ondulados; ápice agudo a obtuso; ápice da costa não denteado

4. Filídios lanceolados; ápice agudo a acuminado .....

4.2. T. langsdorffii

4. Filídios oblongos; ápice obtuso 4.4. T. stenodictyon

4.1 Thamniopsis incurva (Hornsch.) W.R. Buck., Brittonia 39: 218. 1987. Tipo. Chile. Chamisso 1487 (lectótipo BM, designado por Buck 1987).

Fig. 102-110

Gametófito verde-claro pálido, irregularmente ramificado; filídios diferenciados, os laterais oblongos a oblongo-ovados, assimétricos, e os dorsais/ventrais, oblongos a elípticos, simétricos; ápice arredondado a obtuso; margem serreada na $1 / 2$ superior, dentes inflados na 1/2-2/3 superior, não formando dentes e mais alongadas em direção a base, formando uma borda de 1-3 fileiras de células; costa conspícua, desigual, divergente, alcançando 1/2-2/3 do compr. do filídio, ápice projetado na superfície dorsal do filídio; células apicais hexagonais, mais raramente romboidais, longo-romboidais a retangulares em direção à base. Esporófito com seta lisa, avermelhada, cápsula ereta a horizontal. Caliptra não observada.

Material examinado: BRASIL. Rio de Janeiro: Mangaratiba, Km 54 da Rodovia Rio-Santos, Reserva
Ecológica Rio das Pedras, 14/IX/1993, Oliveira-eSilva 657 (HRJ); Rio de Janeiro, entorno do Jardim Botânico do Rio de Janeiro, 80-150 m, 23/III/2004, Braga \& Cardoso 7413 (RB).

Material adicional: BRASIL. Rio Grande do Sul: São Leopoldo, Fazenda São Borja, 40 m, 8/V/1935, Sehnem 16 (PACA).

Thamniopsis incurva dificilmente pode ser confundida com outra espécie de Pilotrichaceae, destacando-se principalmente pela forma do filídio e das células. Segundo Buck (1998), a caliptra é mitrada, com alguns pêlos hialinos e unisseriados.

Apresenta distribuição neotropical, ocorrendo no Brasil nos Estados do PA, AM, PB, BA e regiões sudeste e sul, entre 0-1.400 m. No Rio de Janeiro está amplamente distribuída ocorrendo nos Municípios de Angra dos Reis, Casimiro de Abreu, Itatiaia, Mangaratiba, Niterói, Nova Friburgo, Nova Iguaçu, Parati, Petrópolis, Rio de Janeiro, Silva Jardim e Teresópolis, sobre solo e rochas, geralmente associada a cursos d'água, entre 0-1.100 m. Status de conservação: Baixo Risco (LR). 
4.2 Thamniopsis langsdorffii (Hook.) W.R. Buck., Brittonia 39: 218. 1987. Tipo. Brasil, Rio de Janeiro, Langsdorff s.n. (holótipo BM!).

Fig. 111-118

Thamniopsis beyrichiana (Hampe) Broth., Nat. Pflanzenfam. 1: 941. 1907. Tipo. Brasil, Serra dos Órgãos, 1823, Beyrich (holótipo BM!); syn. nov.

Gametófito púrpuro, irregularmente ramificado; filídios densamente imbricados, diferenciados, os laterais ligeiramente assimétricos e os dorsais/ventrais simétricos, lanceolados a oblongo-lanceolados; ápice agudo a acuminado; margem serreada, com dentes inflados na metade superior do filídio, lineares na metade inferior; costa conspícua, divergente, alcançando $\pm 2 / 3$ do compr. do filídio, ápice não denteado; células apicais e medianas romboidais, mais longas e retangulares em direção à base. Esporófito com seta avermelhada e lisa, cápsula inclinada a pendente. Caliptra não observada.

Material examinado: BRASIL. Rio de Janeiro: Nova Friburgo, Macaé de Cima, Rio das Flores, 1.160 m, 17/VIII/1987, Costa et al. 348 (RB); ibid. Pedra da Catarina, 9/X/1990, Costa et al. 1064 (RB); ibid. São Lourenço, Fazenda Jacarandás, $1.020 \mathrm{~m}$, 29/III/1989, Costa et al. 877 (RB); Rio de Janeiro, Corcovado, Ponte do Inferno, 17/III/1925, Bandeira s.n. (dois exemplares, como Thamniopsis beyrichiana, RB 227096 e RB 227125); ibid. Ule s.n. (como T. beyrichiana, R 82013); ibid. Parque Nacional da Tijuca, 10/IX/1983, Costa 10 (como T. beyrichiana, RB); Teresópolis, Cascata Feroz, V/1917, Sampaio 2702 (dois exemplares, como T. beyrichiana, R 83510 e R 83518); ibid. Granja, estrada de TeresópolisFriburgo, 9/V/1927, Bandeira s.n. (como T. beyrichiana, RB 156668).

Se diferencia de Thamniopsis stenodictyon pelo ápice agudo a acuminado.

Apresenta distribuição neotropical, ocorrendo no Brasil no Estado do CE e Estados das regiões sudeste e sul, entre 0-1.400 m. No Rio de Janeiro ocorre nos Municípios de Angra dos Reis, Itatiaia, Magé, Mangaratiba, Niterói, Nova Friburgo, Petrópolis, Rio de Janeiro e Teresópolis, sobre solo, rocha e troncos caídos, freqüentemente associados a cursos de d'água, entre 0-1.100 m. Status de conservação: Baixo Risco (LR).

4.3 Thamniopsis pendula (Hook.) M. Fleisch., Musci Buitenzorg 3: 952. 1908. Tipo. Equador, Humboldt \& Bonpland s.n. (holótipo BM).

Fig. 119-125
Gametófito verde-claro, com partes avermelhadas, irregularmente ramificado, bipinado ou tripinado; filídios imbricados, ovados a oblongo-lingulados, côncavos ou planos; ápice obtuso, podendo terminar com uma pequena ponta; margem inteira, sem dentes inflados; costa conspícua, divergente na base, quase alcançando o ápice do filídio; células apicais romboidais, medianas mais alongadas e basais retangulares. Esporófito não observado.

Material examinado: BRASIL. Rio de Janeiro: Tijuca, Raddi s.n. (PI).

Material adicional: PANAMÁ. Cerro Colorado: Bocas del Toro, ca. 12 mi above Camp Chami, uncut forest along stream near top of ridge, 1400-1470 m, 20/VI/1987, Allen 5135 (RB).

Uma característica importante desta espécie é a margem inteira, sem dentes inflados. Welch (1976) descreveu a costa como terminando na $1 / 2$ ou um pouco acima, entretanto, no material examinado esta quase atinge o ápice do filídio. Ainda segundo Welch (1976), o esporófito apresenta seta avermelhada, lisa, cápsula pendente e caliptra mitrada, lisa e pilosa.

Apresenta distribuição neotropical e no Brasil, segundo Yano (1981), é citada para o Estado do Rio de Janeiro, por Hornschuch (1840), para o Município do Rio de Janeiro, tendo sido coletada por Raddi na Tijuca; ocorrendo sobre tronco de árvores, possivelmente ao nível do mar. Status de conservação: Dados Deficientes (DD).

Até o momento, foi possível examinar somente o material coletado por Raddi no início do século XIX, no Município do Rio de Janeiro, e depositado no herbário PI. Entretanto, esta é uma espécie com bom status taxonômico que ocorre na América Central e Andes (Churchill \& Linares 1995), e possivelmente rara no Estado.

4.4 Thamniopsis stenodictyon (Sehnem) Oliveira-eSilva \& O. Yano, Bradea 8: 82. 1998. Tipo. Brasil. Rio Grande do Sul, Porto Alegre, 18-XII-1942, Sehnem 556 (holótipo PACA).

Fig. 126-136

Gametófito verde-claro a púrpuro, irregularmente ramificado; filídios diferenciados, os laterais assimétricos e os dorsais/ventrais simétricos, oblongos, raramente ondulados; ápice obtuso; margem fortemente serreada no terço superior, com dentes grandes e inflados; costa conspícua, divergente no ápice, alcançando 2/3 do compr. do filídio; células apicais romboidais, medianas leigeiramente mais longas e basais retangulares. Esporófito não observado. 


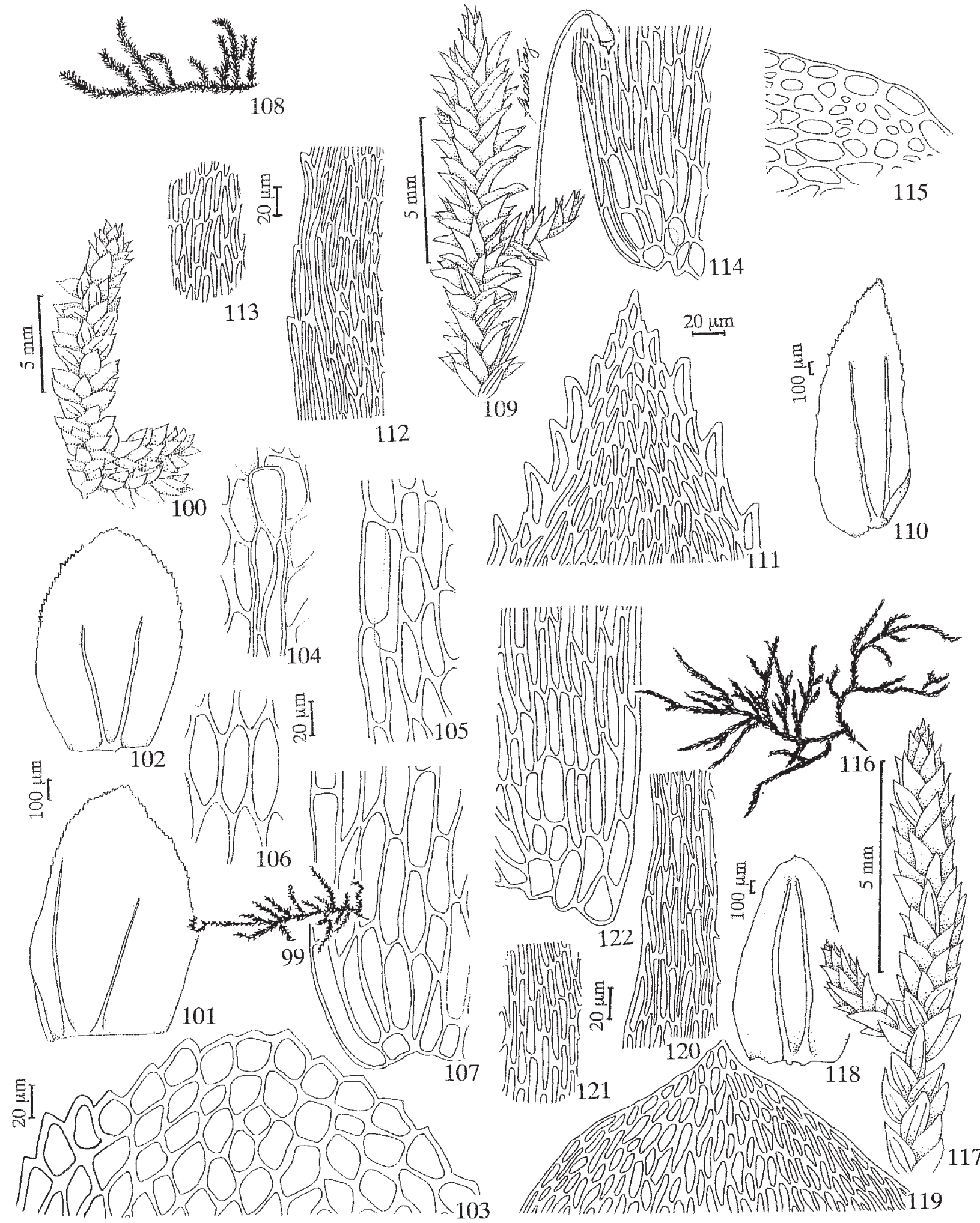

Figuras 99-107. Thamniopsis incurva (Hornsch.) W. R. Buck. 99. Hábito. 100. Detalhe do gametófito. 101. Filídio lateral. 102. Filídio dorsal. 103. Ápice do filídio. 104. Detalhe da costa no ápice. 105. Células da margem do filídio. 106. Células medianas do filídio. 107. Células da base do filídio. Figuras 108-115. Thamniopsis langsdorffii (Hook.) W. R. Buck. 108. Hábito. 109. Detalhe do gametófito com esporófito. 110. Filídio. 111. Ápice do filídio. 112. Células da margem do filídio. 113. Células medianas do filídio. 114. Células da base do filídio. 115. Corte transversal do caulídio. Figuras 116-122. Thamniopsis pendula (Hook.) M. Fleisch. 116. Hábito. 117. Detalhe do gametófito. 118. Filídio. 119. Ápice do filídio. 120. Células da margem do filídio. 121. Células medianas do filídio. 122. Células da base do filídio. 
Material examinado: BRASIL. Rio de Janeiro: Angra dos Reis, Ilha Grande, caminho para o Pico do Papagaio, 600-1.100 m, 21-III-1995, Yano et al. 23689 (SP).

Segundo Sehnem (1979), o esporófito apresenta seta com 1,2-1,7 cm de compr., cápsula pequena, horizontal, opérculo cônico e curto.

Endêmica do Brasil, ocorrendo nos Estados do RJ, SC e RS, entre 200-1.200 m. No Rio de Janeiro ocorre nos Municípios de Angra dos Reis e Niterói, sobre rocha e tronco caído, entre 300-1.100 m. Status de conservação: Baixo Risco (LR).

4.5 Thamniopsis undata (Hedw.) W.R. Buck, Brittonia 39: 219. 1987. Tipo. Jamaica, Swartz s.n. (holótipo G; isótipo NY).

Fig. 134-141

Gametófito verde-amarelado a dourado, irregularmente ramificado, densamente foliado; filídios não diferenciados, contorcidos quando secos, expandidos e ondulados quando molhados, lanceolados a oblongo-lanceolados; ápice longo-acuminado, sempre conspicuamente ondulado; margem diferenciada com 2-3 fileiras de células mais alongadas, serreada acima, com dentes inflados e serrulada em direção a base; costa alcançando 2/3-3/4 do compr. do filídio, ápice denteado na superfície dorsal do filídio; células apicais e medianas longo-romboidais, basais maiores e mais largas. Esporófito não observado.

Material examinado: BRASIL. Rio de Janeiro: Itatiaia, Serra de Itatiaia, Cachoeira de Maromba, 14/X/1926, Bandeira s.n. (RB 174409); Nova Friburgo, 1.190 m, 16/VII/1987, Costa et al. 319 (RB); Nova Iguaçu, Distrito de Tinguá, Reserva Biológica do Tinguá, 29/I/2002, Costa 4093 (RB).

Segundo Buck (1998) o esporófito apresenta seta alongada, lisa ou rugosa somente no extremo ápice, cápsula horizontal a pendente e caliptra mitrada, nua, um pouco rugosa no extremo ápice.

Apresenta distribuição neotropical, ocorrendo no Brasil nos Estados da região sudeste e PR e SC, entre 200-2.300 m. No Rio de Janeiro ocorre nos Municípios de Itatiaia, Nova Friburgo, Nova Iguaçu e Petrópolis, sobre troncos caídos, entre 0-1.200 m. Status de conservação: Baixo Risco (LR).

Espécie excluída do estudo:

Thamniopsis purpureophylla (Müll. Hal.) W.R. Buck - Não foi possível examinar nenhum material dessa espécie oriundo do Rio de Janeiro, o que corrobora a inclusão do táxon por Costa et al. (2005), na categoria de vulnerável. O táxon é conhecido por somente uma coleção realizada por Luetzelburg (1923), para o Município de Teresópolis, há mais de 80 anos.

\section{Discussão}

O estudo das 17 espécies destes quatro gêneros de Pilotrichaceae, incluídas neste estudo, permitiu realizar algumas análises pertinentes ao estado do conhecimento desta família no Estado do Rio de Janeiro e no Brasil, principalmente no que se refere à variação altitudinal, distribuição geográfica e status de conservação dos táxons.

Em relação à variação altitudinal, os dados mostram que a maior riqueza ocorreu na faixa montana, entre 500-1.500 m, que apresentou 14 espécies (40\% do total de espécies de Pilotrichaceae para o Estado), das quais cinco são restritas a esta faixa. Na faixa de terra baixa (0-200 m), ocorreram 10 espécies, na submontana (200-500 m) nove, e na alto montana $(>1.500 \mathrm{~m})$ uma. Duas espécies estão restritas à terra baixa, nenhuma à sub-montana e à alto montana.

A maior riqueza observada na faixa montana já era esperada, visto que nos trópicos estas florestas são mais ricas em número de espécies do que a faixa de terra baixa e sub-montana (Gradstein et al. 2001). Além disso, existem diversas Unidades de Conservação situadas nesta faixa altitudinal no Estado. O grande número de espécies de Pilotrichaceae observado nas florestas de terra baixa do Estado corrobora os dados de Gradstein \& Costa (2003), que sugerem que estas florestas nas regiões tropicais podem ser menos pobres em espécies do que têm sido sugerido.

Somente dois padrões de distribuição, neotropical e endêmico do Brasil, foram observados pelos táxons estudados. Das 17 espécies, 11 (68\%) são neotropicais e seis (32\%) são endêmicas do Brasil.

Das espécies estudadas, três espécies (19\%) apresentam ampla distribuição, ocorrendo em mais de três regiões do Brasil, 10 espécies (56\%) ocorrem exclusivamente nas regiões sul e sudeste, três $(21 \%)$ são endêmicas do Estado do Rio de Janeiro e uma (16\%) ocorrendo de maneira descontínua entre o sudeste e outras regiões. Estes dados indicam a importância das espécies destes gêneros de Pilotrichaceae na região sudeste do Brasil, que pode ser considerada um dos centros de diversidade da família no país. Além disso, a distribuição descontínua de $6 \%$ das espécies pode indicar tanto a carência de coletas em áreas intermediárias, bem como a baixa representatividade das espécies de Pilotrichaceae nestas áreas, uma vez que esta família está 


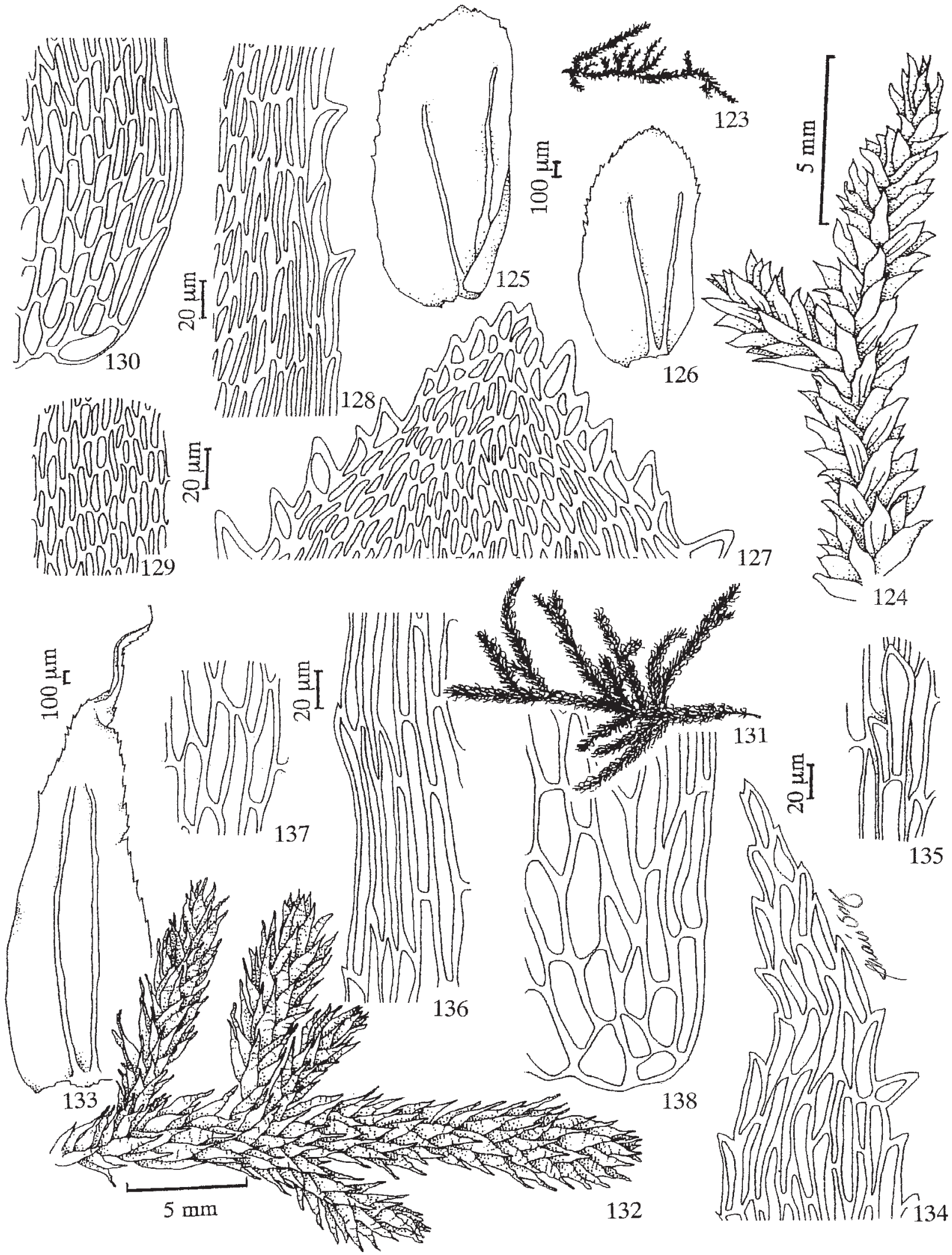

Figuras 123-130. Thamniopsis stenodictyon (Sehnem) Oliveira-e-Silva \& Yano. 123. Hábito. 124. Detalhe do gametófito. 125. Filídio lateral. 126. Filídio dorsal. 127. Ápice do filídio. 128. Células da margem do filídio. 129. Células medianas do filídio. 130. Células da base do filídio. Figuras 131-138. Thamniopsis undata (Hedw.) W.R. Buck. 131. Hábito. 132. Detalhe do gametófito. 133. Filídio. 134. Ápice do filídio. 135. Detalhe da costa no ápice. 136. Células da margem do filídio. 137. Células medianas do filídio. 138. Células da base do filídio. 
preferencialmente distribuída em regiões úmidas.

Dos 92 municípios do Estado do Rio de Janeiro, somente 14 apresentam registros das 17 espécies de Pilotrichaceae tratadas neste estudo. Este fato demonstra que o Estado ainda é carente de levantamentos florísticos de briófitas, visto que muito dos municípios ainda apresentam formações vegetais bem preservadas em Unidades de Conservação. Este fato demonstra que o Estado ainda é carente de levantamentos florísticos de briófitas, onde, das 38 Unidades de Conservação, nove têm a sua brioflora totalmente desconhecida.

Com base nos dados disponíveis até o momento, é possível afirmar que os municípios do Estado do Rio de Janeiro que apresentaram maior riqueza são Nova Friburgo e Itatiaia, provavelmente por estarem situados na faixa com maior riqueza de espécies desta família no estado, por apresentarem Unidades de Conservação e por possuírem pesquisas com a sua brioflora, demonstrando a importância deste tipo de estudo para o conhecimento da flora do Estado.

Novas ocorrências da família são citadas neste estudo para cinco municípios do Estado do Rio de Janeiro, incluindo uma para o Brasil, Lepidopilum longifolium, e outra para o Estado do Rio de Janeiro, Lepidopilum surinamense, enfatizando a importância de se examinar material de diversos herbários que contenham coleções de briófitas.

Os dados sobre o status de conservação dos táxons no Rio de Janeiro demonstram que a família se apresenta em bom estado de conservação, visto que 13 espécies $(76 \%)$ apresentam baixo risco, duas espécies $(12 \%)$ foram consideradas vulneráveis e apenas uma (6\%) ameaçada. Isto se deve possivelmente a ampla distribuição das espécies na Mata Atlântica do Estado e por ocorrerem em áreas protegidas por Unidades de Conservação.

\section{Agradecimentos}

As autoras agradecem aos curadores dos herbários BM, G, HRJ, SP, PACA, PI, R, RB e RFFP, pelo empréstimo dos materiais; ao Prof. Paulo Eduardo Aguiar Saraiva Câmara, do Missouri Botanical Garden, pelo envio de bibliografia. A primeira autora agradece a CAPES, pela bolsa concedida.

\section{Referências bibliográficas}

Allen, B. 1986. The taxonomic status of Hypnella punctata. The Bryologist 89: 224-226.
Allen, B. 1990. A revision of the Genus Crossomitrium (Musci: Hookeriaceae). Tropical Bryology 2: 3-34.

Bartram, E.B. 1954. Musci. Pp. 234-242. In: C.T. Rizzini. Flora Organensis. Lista preliminar dos Cormophyta da Serra dos Órgãos. Archivos do Jardim Botânico do Rio de Janeiro 13.

Brotherus, V.F. 1894. Musci Schenckiani. Ein Beitrag zur Kenntniss der Moosflora Brasiliens. Hedwigia 33: 127-136.

Brotherus, V.F. 1895a. Beiträge zur Kenntniss der brasilianischen Mossflora. Hedwigia 34: 117-131.

Brotherus, V.F. 1895b. Nouvelles contributions à la flore bryologique du Brésil. Bihang til Kongliga svenska vetenskaps-akademiens handlingar 21(3): 3-76.

Brotherus, V.F. 1907. Musci (Laubmoose). In: A. Engler \& K. Prantl. Die Natürlichen Pflanzenfamilien I(3): 918-962.

Brotherus, V.F. 1924. Musci (Labmoose). Pp. 251-358. In: Ergebnisse der botanischen Expedition der Kaiserlichen Akademie der Wissenschaften nach Südbrasilien 1901, herausgegeben von Prof. Dr. V. Schiffner. Denkschriften der Kaiserlichen Akademie der Wissenschaften. Mathematisch-naturwissenschaftliche Klasse.

Buck, W.R. 1987. Taxonomic and nomenclatural rearrangement in the Hookeriales with notes on West Indian taxa. Brittonia 39: 210-224.

Buck, W.R. 1998. Pleurocarpous mosses of the West indies. Memoirs of The New York Botanical Garden 82: 1-400.

Buck, W.R. \& Goffinet, B. 2000. Morphology and classification of mosses. Pp. 71-123. In: A.J. Shaw \& B. Goffinet (eds.). Bryophyte Biology. England, Cambridge University Press.

Churchill, S.P. 1988. A revision of the moss genus Lepidopilum (Callicostaceae). PhD. Dissertation, City University of New York.

Churchill, S.P. 1998. Catalog of Amazonian Mosses. The Journal of the Hattori Botanical Laboratory 85 : 191-238.

Churchill, S.P \& Linares, C. 1995. Prodromus bryologiae, Novo-Granatensis: introducción a la flora de musgos de Colombia. Parte 1: Adelotheciaceae a Funariaceae. Biblioteca Jose Jeronimo Triana 12: 1-453.

Costa, D.P. 1995. Musgos do Município de Nova Friburgo, Rio de Janeiro, Brasil. Arquivos do Jardim Botânico do Rio de Janeiro 33: 99-118.

Costa, D.P.; Imbassahy, C.A.A. \& Silva, V.P.A.V. 2005. Diversidade e importância das espécies de briófitas na conservação dos ecossistemas do estado do Rio de Janeiro. Rodriguésia 56(87): 13-49.

Crosby, M.R. 1969. A Revision of the Tropical American Moss Genus Pilotrichum. The Bryologist 72: 275-343.

Crosby, M.R.; Magill, R.E. \& Allen, B. 1985. A review of the moss genus Hypnella. The Bryologist 88: 121-129.

Crosby, M.R.; Magill, R.E.; Allen, B. \& He, S. 1999. A Checklist of the Mosses. St. Louis, USA, Missouri Botanical Garden.

Dusén, P. 1903. Sur la flore de la Serra do Itatiaya au Brésil. Arquivos do Museu Nacional do Rio de Janeiro 13: 1-119. 
Florschütz-de-Waard, J. 1986. Musci. Part II. Pp. 273-361. In: A.L. Stoffers \& J.C. Lindeman (eds.). Flora of Suriname. v. 6. Brill, Leiden.

Gradstein, S.R. \& Costa, D.P. 2003. The Hepaticae and Anthocerotae of Brazil. Memoirs of the New York Botanical Garden 88: 1-318.

Gradstein, S.R.; Churchill, S.P. \& Salazar-Allen, N. 2001. Guide to the Bryophytes of the Tropical America. Memoirs of The New York Botanical Garden 86: 1-577.

Greuter, W.; McNeill, J.; Barrie, F.R.; Burdet, H.M.; Demoulin, V.; Filgueiras, T.S.; Nicolson, D.H.; Silva, P.C.; Skog, J.E.; Trechane, P.; Turland, N.J. \& Hawksworth, D.L. (eds.). 2003. Código Internacional de Nomenclatura Botânica (Código de Saint Louis, 2000), versão em português. Regnum Vegetabile 138. Germany, Koeltz Scientific Books.

Hampe, E. 1872. Musci frondosi. Pp. 36-59. In: Warming (ed.). Symbolae ad floram Brasiliae centrales cognoscendam. Videnskabelige Meddelelser fra dansk naturhistoriske Forening i Kjöbenhavn, ser. 3, 10.

Hampe, E. 1874a. Musci frondosi. Pp. 129-178. In: Warming (ed.). Symbolae ad floram Brasiliae centrales cognoscendam. Videnskabelige Meddelelser fra dansk naturhistoriske Forening i Kjöbenhavn, ser. 3, 19.

Hampe, E. 1874b. Musci frondosi. Pp. 73-141. In: Warming (ed.). Symbolae ad floram Brasiliae centrales cognoscendam. Videnskabelige Meddelelser fra dansk naturhistoriske Forening i Kjöbenhavn, ser. 3, 19.

Hampe, E. 1877. Musci frondosi. Pp. 251-274. In: Warming (ed.). Symbolae ad floram Brasiliae centrales cognoscendam. Videnskabelige Meddelelser fra dansk naturhistoriske Forening i Kjöbenhavn, ser. 3, 24.

Hampe, E. 1879. Enumeratio muscorum hactenus in provinciis Brasiliensibus Rio de Janeiro et São Paulo detectorum. Videnskabelige Meddelelser fra dansk naturhistoriske Forening i Kjöbenhavn 26: 73-164.

Hampe, E. \& Geheeb, A. 1881. Additamenta ad "Enumerationem hactenus in provinciis Brasiliensibus Rio de Janeiro et São Paulo detectorum". Flora 64: 337-347, 369-381, 401-416, 433-438.

Herzog, T. 1927. Zwei Bryophyten Sammlungens aus SüdAmerika. Hedwigia 67: 249-268.

Hornschuch, C.F. 1840. Musci. Pp. 1-100. In: C.F. Martius (ed.). Flora Brasiliensis enumeratio plantarum in Brasilia hactenus detectarum quas suis aliorumque botanicorum studiis descriptas et methodo naturali digestas partim icone ilustratas 1(2).

Lisboa, R.C.L. \& Maciel, U.N. 1994. Musgos da Ilha de Marajó - I - Afuá (Pará). Boletim do Museu Paraense Emílio Goeldi, sér. Bot., 10: 43-55.

Lisboa, R.C.L.; Lima, M.J.L. \& Maciel, U.N. 1999. Musgos da Ilha de Marajó - II - Município de Anajás, Pará, Brasil. Acta Amazonica 29: 201-206.

Luetzelburg, A. 1923. Estudos botânicos do Nordeste. Inspetoria Federal de Obras contra Seccas 3: 1-283 (Bryophyta, 232-238).

Magill, E.R. (ed.). 1990. Glossarium Polyglottum Bryologiae. A multilingual glossary for bryology. Monographs in Systematic Botany from the Missouri Botanical Garden 33: 1-297.
Müller, C. 1856. Symbolae ad synopsim muscorum. Botanische Zeitung 14: 415-421, 436-440, 455-459.

Müller, C. 1859. Supplementarum novorum ad synopsis muscorum. Botanische Zeitung 17: 197-198, 214-215, 246-248.

Müller, C. 1898. Bryologia Serrae Itatiaiae. Bulletin de L'Herbier Boissier 6: 18-48.

Müller, C. 1899. Contributiones ad bryologiam austro-afram. Hedwigia 38: 52-155.

Müller, C. 1900. Symbolae ad bryologiam Brasiliae et regionorum vicinarum. Hedwigia 39: 235-289.

Müller, C. 1901. Genera Muscorum Frondosorum: i-vii + $1-474$.

Oliveira-e-Silva, M.I.M.N. \& Yano O.1998. Thamniopsis stenodictyon (Sehnem) Oliveira-e-Silva \& Yano, comb. nov. Bradea 8: 81-84.

Oliveira-e-Silva, M.I.M.N. \& Yano O. 2000. Musgos de Mangaratiba e Angra dos Reis, Rio de Janeiro, Brasil. Boletim do Instituto de Botânica 14: 1-137.

Projeto Flora do Estado do Rio de Janeiro: Bases para o Uso Sustentável da Diversidade Vegetal. 2002 (inédito).

Santos, R.C.P. \& Lisboa. R.C.L. 2003. Musgos (Bryophyta) do Nordeste Paraense, Brasil - I - Zona Bragantina, Microrregião do Salgado e Município de Viseu. Acta Amazonica 33: 415-422.

Schäfer-Verwimp, A. 1989. New or interesting records of Brazilian bryophytes, II. The Journal of the Hattori Botanical Laboratory 67: 313-321.

Schäfer-Verwimp, A. 1992. New or interesting records of Brazilian bryophytes, III. The Journal of the Hattori Botanical Laboratory 71: 55-68.

Schiffner, V. \& Arnell, S. 1964. Ergebnisse der botanischen Expedition der kaiserlichen Akademie der Wissenschaften nach Südbrasilien 1901. II. Hepaticae. Österreichische Akademie der Wissenschaften, Mathematische-naturwissenschaftlische Klasse. Denkschriften 111: 1-156.

Sehnem, A. 1979. Musgos sul-brasileiros. 6. Pesquisas, ser. Bot. 33: 1-149.

Welch, W.H. 1976. Hookeriaceae. North America Flora, ser. 2, 9: 1-133.

Wijk, R. van der; Margadant, W.D. \& Florschütz, P.A. 1959-1969. Index Muscorum. I-V. Regnum Veg. 17, 26, 33, 48, 65. Utrecht, International Association for Taxonomy.

Yano, O. 1981. A Checklist of Brazilian Mosses. The Journal of the Hattori Botanical Laboratory 50: 279-456.

Yano, O. 1989. An additional checklist of Brazilian bryophytes. The Journal of the Hattori Botanical Laboratory 66: 373-434.

Yano, O. 1995. A new additional annotated checklist of Brazilian bryophytes. The Journal of the Hattori Botanical Laboratory 78: 137-182.

Yano, O. 1996. A Checklist of the Brazilian Bryophytes. Boletim do Instituto de Botânica 10: 47-232.

Yano, O. \& Lisboa, R.C.L. 1988. Briófitas do território Federal do Amapá, Brasil. Boletim do Museu Paraense Emílio Goeldi, sér. Bot., 4: 243-270. 